Published by LPMP Imperium

Journal homepage: https:/ / ejournal.imperiuminstitute.org/ index.php/ AKURASI

\section{Pengaruh E-Banking dan Good Corporate Governance terhadap Kinerja Perbankan di Indonesia}

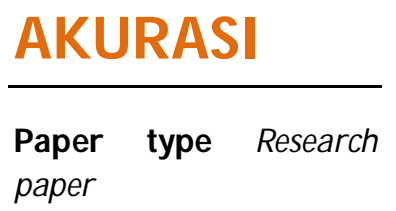

Wisnu Handoyo Murti

Akuntansi, Sekolah Tinggi Ilmu Ekonomi Indonesia Jakarta

\begin{abstract}
This study aims to examine the effect of e-banking and the implication of good corporate governance on banks performance. The rapid movement of digital technology in dealing with transaction provides both challenges and opportunities. Banks should understand the digital trend to survive in the digital era, while good corporate governance practice will impact banks performance through planning strategies and decision making. This paper use panel regression to analyze the data and banks listed in Indonesia Stock Exchange is used as a sample. The result indicates that ebanking, the board size, and institutional ownership do not statistically significant in influencing banks performance. While ownership concentration and the independent commissioner has a positive effect on banks performance.
\end{abstract}

Keywords: e-banking, good corporate governance, banks performance

\begin{abstract}
Abstrak
Penelitian ini bertujuan untuk menguji pengaruh e-banking dan implikasi dari tata kelola perusahaan yang baik terhadap kinerja bank. Pergerakan cepat teknologi digital dalam menangani transaksi memberikan tantangan dan peluang. Bank harus memahami tren digital untuk bertahan di era digital, sementara praktik tata kelola perusahaan yang baik akan berdampak pada kinerja bank melalui strategi perencanaan dan pengambilan keputusan. Makalah ini menggunakan regresi panel untuk menganalisis data dan bank yang terdaftar di Bursa Efek Indonesia digunakan sebagai sampel. Hasilnya menunjukkan bahwa e-banking, ukuran dewan, dan kepemilikan institusional tidak signifikan secara statistik dalam mempengaruhi kinerja bank. Sedangkan konsentrasi kepemilikan dan komisaris independen berpengaruh positif terhadap kinerja bank.
\end{abstract}

Kata Kunci e-banking, good corporate governance, kinerja bank

$\triangle$ Email korespondensi:wisnuhanmurti@gmail.com

Pedoman Sitasi: Wisnu Hardoyo Murti (2019). Pengaruh E-Banking dan Good Corporate Governance terhadap Kinerja Perbankan di Indonesia. AKURASI, 1(1), 21 - 30
Received: 14 Mar 2019

Accepted: 15 Jun 2019

Online: 1 Jul 2019

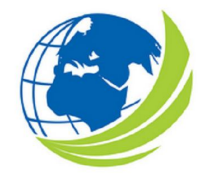

Akurasi: Jurnal Riset Akuntansi dan Keuangan, Vol 1, No.1, Agustus 2019, pp. 21 - 30

eISSN 2685-2888 


\section{PENDAHULUAN}

Teknologi merupakan hal yang penting dalam kehidupan individudan menjadi pemicu kegiatan bisnis nomor 1. Saat ini, transaksi dengan menggunakan media digital berkembang sangat pesat, bahkan melebihi dari kegiatan yang dilakukan pada cabang-cabang tradisional perbankan untuk pertama kalinya di Indonesia. Berdasarkan studi yang dilakukan oleh PWC, perusahaan-perusahaan perbankan di Indonesia sangat berusaha untuk beradaptasi dan menyesuaikan diri dengan perubahan teknologi yang terjadi saat ini dan hanya $8 \%$ responden yang mengatakan bahwa perusahaannya masih memiliki strategi yang sama seperti yang mereka lakukan 18 bulan yang lalu. Sektor apapun, termasuk di dalamnya perbankan harus memiliki strategi yang jelas terkait dengan penggunaan teknologi untuk menghadapi persaingan di era digital.

Perbankan khususnya, harus membuat strategi yang jelas, fokus pada customers, penerapan strategi melalui eksekusi yang tepat, dan berinvestasi pada kegiatan manajemen risiko (PWC, 2018). Perusahaan perbankan di Indonesia juga mengalami event yang cukup menantang di tahun 2015 dan 2016 karena harga komoditas yang murah, harga minyak dan gas yang cenderung murah, menyebabkan pergolakan pada nilai kurs dan ekonomi makro yang kurang stabil, juga peningkatan NPL atau non-performing loan, akan tetapi sektor perbankan masih tetap tumbuh di tahun 2016 (EY, 2017).

Transaksi dengan menggunakan paltform digital, salah satunya melalui penggunaan ebanking, menjadi salah satu komoditas dan sumber strategi utama untuk mencapai tingkat efisiensi yang lebih tinggi di sektor perbankan, pengendalian pada kegiatan operasional, dan juga yang sangat penting adalah cost reduction dengan mengganti kegiatan yang menggunakan paper based dan labour intensive menjadi lebih terotomatisasi yang diharapkan dapat meningkatkan kinerja perbankan (Malholtra \& Singh, 2009). Perilaku konsumen yang saat ini lebih menyukai berbelanja online juga mendorong konsumen untuk menggunakan internet banking dengan lebih intensif. Oleh karena itu, sangat penting bagi perusahaan-perusahaan perbankan untuk terus melihat tren perkembangan teknologi, khususnya teknologi digital untuk dapat merumuskan strategi yang tepat.

Krisis ekonomi global yang terjadi selama beberapa periode memberikan informasi kepada kita mengenai bagaimana sebaiknya merumuskan strategi yang tepat dan perlunya menerapkan prinsip kehati-hatian (act prudent) dalam mengambil keputusan, dan juga sangat penting bagi perusahaan untuk menerapkan praktek good corporate governance dalam pengambilan keputusan untuk meminimalkan risiko melalui adanya transparansi, dan juga kegiatan manajerial yang lebih akuntabel. Beberapa penelitian menunjukkan bahwa pelaksanaan atau praket good corporate governance memberikan dampak positif bagi kinerja perusahaan perbankan (Fanta, Kemal, \& Waka, 2013). Sedangkan penelitian yang dilakukan oleh Onakoya, Ofoegbu, \& Fasanya (2012) juga menunjukkan hal yang serupa, bahwa praktek good corporate governance berpengaruh terhadap kinerja perusahaan perbankan di Nigeria.

Penerapan good corporate governance yang tepat juga dapat membantu perusahaan untuk memiliki strategi yang tepat dalam menerapkan manajemen risiko, dengan manajemen risiko yang tepat diharapkan juga dapat meningkatkan kinerja perusahaan. Salah satu penerapan good corporate governance terkait dengan risk taking behavior perusahaan perbankan adalah dengan adanya struktur kepemilikan yang tepat dan pemilihan komite audit (Lestari, 2018). Kinerja, selalu menjadi tolak ukur suksesnya sebuah bisnis. Akan tetapi, untuk dapat memiliki kinerja yang stabil dan sustain, diperlukan berbagai strategi yang tepat. Penelitian ini fokus pada sektor perbankan karena penggunaan e-banking diprediksi akan lebih masif ke depannya, dan sektor perbankan merupakan salah satu sektor yang harus memiliki respon yang cepat terhadap perubahan teknologi. Selain itu, kegiatan perbankan yang mengedankan prinsip kehati-hatian dan tetap agresif merupakan prinsip unik yang tidak dimiliki semua sektor. Penerapan corporate governance akan membantu perusahaan untuk tetap agresif dan berhati-hati dalam waktu yang sama. 


\section{KAJIAN PUSTAKA DAN MODEL PENELITIAN}

Kinerja Sektor Perbankan di Indonesia

Sektor perbankan memiliki peranan penting dalam suatu perekonomian. Bank, pada dasarnya merupakan suatu fungsi yang bertugas menjembatani antara pihak yang memiliki kelebihan dana (surplus dana) dan pihak yang mengalami kekurangan dana (defisit dana)., dan juga merupakan tempat yang menyediakan jasa keuangan, khususnya menyediakan layanan transaksi yang dapat meningkatkan kualitas hidup masyarakat dan membantu efektivitas dan efisiensi sebuah bisnis (American Bankers Association, 2014). Pada bulan Mei 2018, bank di Indonesia kehilangan sekitar 15\% kapitalisasi pasar selama bebera bulan karena adanya penurunan rupiah, dan juga dampak dari adanya peningkatan suku bunga (DBS Group Research, 2018). Saat ini, transaksi berbasis digital diperkirakan akan mengganti transaksi tradisional dan hal tersebut tentunya akan berdampak pada teknologi keuangan yang juga akan bertumbuh. Hal tersebut menjadi sebuah alat yang penting untuk meningkatkan inklusi keuangan dan membantu masyarakat untuk bertransaksi.

Perkembangan fintech atau financial technology mendorong transaksi berbasis digital berkembang pesat. Bank, dengan berbagai layanan keuangan yang diberikan, diharapkan mampu bertahan dan dapat bersaing dengan berbagai layanan keuangan berbasis teknologi yang saat ini tengah berkembang. Di masa depan, sektor perbankan di Indonesia yang berbasis digital tengah berkembang, khususnya e-branch atau cabang elektronik yang diperkirakan akan menggantikan cabang tradisional di beberapa tahun mendatang. Pernyataan tersebut juga didukung oleh Indonesia Banking Survey di tahun 2017 yang dilakukan oleh PWC, 89\% responden mengatakan bahwa mereka mengharapkan aplikasi berbasis digital (mobile application) dalam melakukan transaksi, sedangkan transaksi berbasis website dan web-based platform menempati peringkat kedua (oxfordbusinessgroup.com, 2018).

Internet Banking

Meningkatnya penggunaan digitalisasi pada pasar dunia terjadi di berbagai industry, termasuk transaksi elektronik yang mempengaruhi strategi yang perlu dikembangkan oleh bank dan institusi keuangan. Pesatnya inovasi di bidang teknologi keuangan saat ini, yang dibarengi dengan banyaknya pengguna (mengingat Indonesia merupakan salah satu negara dengan penduduk terbesar di dunia, yaitu sekitar 250juta jiwa), Indonesia juga memiliki proporsi penduduk muda yang besar dan mampu mengoperasikan teknologi dengan baik, menjadi pasar yang menarik untuk pasar digital, khususnya transaksi digital. Indonesia, dengan ribuan pulau dan memiliki struktur geografi yang cukup unik akan memiliki keuntungan dengan menerapkan digital banking, khususnya platform dengan karakteristik yang fleksibel dan murah (oxfordbusinessgroup.com, 2018). Terdapat beberapa faktor yang memotivasi perusahaan perbankan dalam mengimplementasikan internet banking, misalnya: cost advantage, profitabilitas yang tinggi, dan adanya risiko yang rendah. Penelitian menunjukkan bahwa investasi pada internet banking akan memberikan laba secara cepat jika terdapat permintaan yang cukup untuk internet banking (Tunay, Tunay, \& Akhisar, 2015).

Sebuah penelitian menunjukkan bahwa 57\% commercial banks di India menyediakan jasa layanan internet banking, dan perusahaan di sektor perbankan akan memperoleh manfaat yang lebih melalui rasio efisiensi dan rasio profitabilitas yang cenderung lebih tinggi jika dibandingkan dengan perusahaan perbankan yang tidak menerapkan internet banking (Malholtra \& Singh, 2009). Transformasi yang terjadi pada sektor perbankan dan juga institusi keuangan yang lain, pada dasarnya ditentukan oleh tren layanan yang ingin dan saat ini digunakan oleh masyarakat, dan penerapan teknologi informasi akan membantu sebuah bisnis untuk beroperasi lebih efisien dan lebih murah. Di Kenya, pembayaran online sangat popular dan transaksi dengan menggunakan layanan mobile banking sangat sering digunakan (Okiro \& Ndungu, 2013). Internet banking, membantu bank untuk melakukan penetrasi layanan perbankan tanpa perlu menempatkan layanan fisik, dan hal tersebut berdampak positif terhadap kinerja bank jika dikaitkan dengan time reduction 
dan peningkatan kualitas layanan (Kombe \& Wafula, 2015).

H1 : e-banking berpengaruh terhadap kinerja perusahaan perbankan

Good Corporate Governance

Corporate governance dapat didefinisikan sebagai sebuah sistem yang ada di organisasi dan sistem tersebut menjadi pemiliknya akan menerima tingkat pengembalian yang fair atas investasinya, dan juga menjadi jembatan antara para pemegang saham, direktur, jajaran manajemen, staf, konsumen, dan komunitas secara luas (Clarkson \& Deck, 1997). Arora \& Sharma (2016) menyatakan bahwa jumlah board of directors yang lebih besar, diasosiasikan dengan pengetahuan intelektual yang lebih dalam dan diharapkan dapat membantu dalam pengambilan keputusan yang berdampak positif terhadap kinerja perushaan. Seberap penelitian menunjukkan penerapan good corporate governance berpengaruh positif terhadap kinerja perusahaan.

Deloitte (2016) menyebutkan bahwa corporate governance dan kinerja merupakan topik menarik dan sering menjadi sorotan pada debat publik, hal tersebut erat kaitannya dengan budaya organisasi, praktek manajemen risiko, penerapan kebijakan, dan lain sebagainya. Good corporate governance meningkatkan tata kelola perusahaan dan terdapat 6 variabel penting dalam praktek tersebut, antara lain: board independensi, board diversity, remunerasi, karakteristik CEO, pengawasan dan struktur kepemilikan. Praktek good corporate governance dapat meningkatkan proses pengambilan keputusan dan kinerja perusahaan.

$\mathrm{H} 2$ : board size berpengaruh terhadap kinerja perusahaan perbankan

H3: komisaris independen berpengaruh terhadap kinerja perusahaan perbankan

H4: kepemilikan terkonsentrasi berpengaruh terhadap kinerja perusahaan perbankan

H5: kepemilikan institusional berpengaruh terhadap kinerja perusahaan perbankan

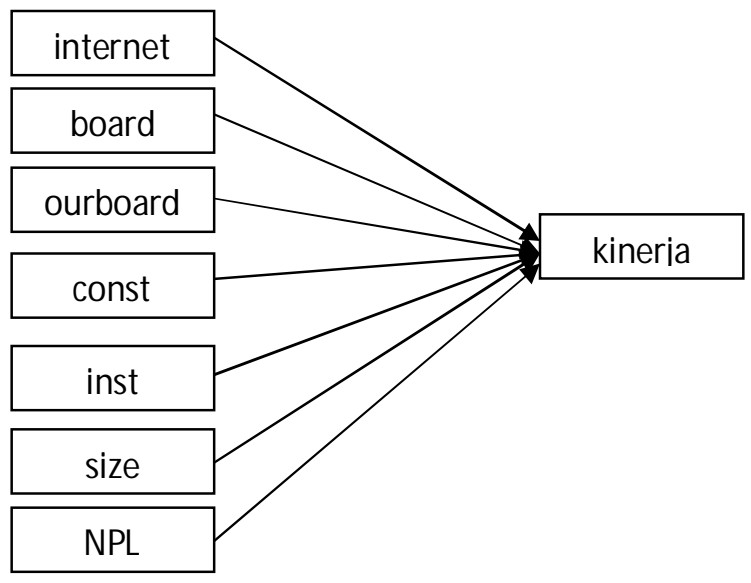

Gambar 1. Kerangka Model Penelitian 
AKURASI, 1(1), 21-30

Wisnu Hardoyo Murti. Pengaruh E-Banking dan Good Corporate ...

\section{METODE PENELITIAN}

Desain Penelitian

ini merupakan penelitian kuantitatif, yang menekankan analisisnya berdasarkan pada angka dengan metode statistik untuk menguji hipotesis. Penelitian ini bertujuan untuk menganalisa pengaruh ebanking dan good corporate governance terhadap kinerja sektor perbankan yang terdaftar di Bursa Efek Indonesia dari tahun 2008-2016. Data yang digunakan dalam penelitian ini adalah data sekunder yang diperoleh dari Bursa Efek Indonesia.

Populasi dan Sampel

Populasi dalam penelitian ini adalah perusahaan perbankan yang terdaftar di Bursa Efek Indonesia dari tahun 2008 sampai dengan tahun 2016. Teknik sampling dalam penelitian ini adalah purposive sampling dengan mengikuti kriteria sebagai berikuta; aktif dan terdaftar di Bursa Efek Indonesia dari tahun 2007 dan tidak pernah delisting selama periode pengamatan, dan memiliki laporan keuangan yang lengkap.

Pengukuran Variabel

Variabel dependen dalam penelitian ini adalah Kinerja. Sedangkan variabel independennya adalah ebanking, board size, komisioner independen, kepemilikan terkonsentrasi, dan kepemilikan institusional. Sedangkan variabel kontrol dalam penelitian ini adalah size dan NPL. Berikut merupakan pengukuran variabel dalam penelitian ini (Brigham \& Houston, 2006; Okiro \& Ndungu, 2013; Arora \& Sharma (2016)):

PERFORM adalah kinerja yang diukur dengan menggunakan Return on Asset (ROA) dengan formula sebagai berikut:

ROA $=$ Net income $/$ Total Asset

INTERNET Dummy variable dengan nilai 1 jika perusahaan perbankan mengadopsi e-banking BOARD Jumlah board of directors

OUTBOARD adalah Persentase komisioner independen

OWNS adalah Persentase pemegang saham terbesar

INST adalah Persentase pemilik atas nama institusi

Control Variable

SIZE adalah ukuran perusahaan yang dihitung dengan $=\log$ (total asset)

NPL atau Non Performing Loan diukur dengan formula berikut:

NPL = Total Non Performing Loan / Total Loan

Teknik Analisis

Penelitian ini merupakan penelitian kuantitatif dengan menggunakan data panel. Data panel merupakan jenis data yang menggabungkan antara data cross section dan time series. Sehingga untuk melakukan analisa dalam penelitian ini, digunakan regresi panel. 


\section{HASIL DAN PEMBAHASAN}

Statistik Deskriptif

Tabel 2 menjelaskan mengenai statistik deskriptif pada masing-masing variabel. E-banking yang diadopsi oleh perusahaan perbankan di Indonesia memiliki nilai maksimal 1, dan nilai minimum 0 . Sementara board size memiliki nilai maksimum 1.146 dan nilai minimum 0.48. Kepemilikan institusional memiliki nilai maksimum 1, dan nilai minimum 0.1 , kepemilikan terkonsentrasi memiliki nilai maksimum 1 dan nilai minimum 0.11 , komisioner independen memiliki nilai maksimum 0.86 dan nilai minimum 0.3. Sedangkan NPL memiliki nilai maksimum 20.51 dan nilai minimum 0.01. Sedangkan nilai size memiliki nilai maksimum 9.02 dan nilai minimum 6.13.

Tabel .2 Statistik Deskriptif

\begin{tabular}{crrrrr}
\hline & Mean & Median & Max & Min & $\begin{array}{l}\text { Std. } \\
\text { Dev }\end{array}$ \\
\hline \hline INTERNET & 0.51 & 1 & 1 & 0 & 0.50 \\
BOARD & 0.83 & 0.85 & 1.15 & 0.48 & 0.17 \\
INST & 0.75 & 0.82 & 1.00 & 0.10 & 0.21 \\
OUT & 0.63 & 0.63 & 0.86 & 0.30 & 0.11 \\
CONST & 0.57 & 0.58 & 1.00 & 0.11 & 0.21 \\
NPL & 1.73 & 1.23 & 20.51 & 0.01 & 2.09 \\
SIZE & 7.49 & 7.40 & 9.02 & 6.13 & 0.76 \\
Observasi & 243 & 243 & 243 & 243 & 243 \\
\hline \hline
\end{tabular}

Sumber : diolah

Multikolinearitas

Penelitian ini menggunakan matriks korelasi untuk menguji multikolinearitas. Tabel 2 menunjukkan pengujian multikolinearitas yang mengindikasikan antar variable independen tidak memiliki kolinearitas yang tinggi, karena memiliki nilai matriks korelasi di bawah 0.8 .

Tabel 3. Correlation Matrix

\begin{tabular}{lrrrrrrr}
\hline & INST INTERNET & NPL & OUT SIZE CONST BOARD \\
\hline \hline INST & 1 & & & & & & \\
INTERNET & 0.06 & 1 & & & & & \\
NPL & 0.18 & -0.19 & 1 & & & & \\
OUT & 0.10 & 0.36 & -0.17 & 1 & & & \\
SIZE & -0.09 & 0.69 & -0.32 & 0.51 & 1 & & \\
CONST & 0.41 & 0.18 & 0.12 & 0.17 & 0.00 & 1 & \\
BOARD & 0.03 & 0.59 & -0.32 & 0.49 & 0.88 & 0.08 & 1 \\
\hline
\end{tabular}

Sumber : diolah

Pembahasan

Tabel 3 menunjukkan hasil analisis regresi panel, yang dapat disimpulkan bahwa Fixed Effect merupakan model yang paling sesuai jika dibandingkan dengan Common Effect dan Random Effect. Berdasarkan table 4 (kolom fixed effect), e-banking, board size, dan kepemilikan institusional tidak berpengaruh terhadap kinerja perbankan. Sedangkan komisioner independen dan kepemilikan terkonsentrasi berpengaruh terhadap kinerja perbankan. 
AKURASI, 1(1), 21-30

Wisnu Hardoyo Murti. Pengaruh E-Banking dan Good Corporate ...

Berdasarkan tabel 3, data menunjukkan bahwa e-banking tidak berpengaruh terhadap kinerja perbankan di Indonesia, hal tersebut menunjukkan bahwa penerapan e-banking tidak berpengaruh terhadap profitabilitas perbankan di Indonesia (Furst, Lang, \& Nolle, 2000). Selain itu, hal itu menunjukkan bahwa penerapan e-banking pada dasarnya merupakan hal yang memang perlu dilakukan. Akan tetapi, dalam penggunaannya, adopsi terhadap platform e-banking merupakan suatu proses yang ada pada masing-masing individu. Perbankan sendiri memiliki berbagai layanan, terdapat banyak factor yang menarik individu untuk menggunakan produk perbankan di Indonesia, misalnya banyaknya cabang, tingkat suku bunga, layanan yang diberikan, dan lain sebagainya, sehingga e-banking bukan satu-satunya factor yang menentukan kinerja perusahaan. Akan tetapi, penerapan e-banking merupakan keharusan bagi perusahaan yang bergerak di sektor perbankan.

Tabel 3. Hasil Penelitian

\begin{tabular}{|c|c|c|c|c|c|c|c|c|c|}
\hline \multirow{2}{*}{ Variabel } & \multicolumn{3}{|c|}{ CE } & \multicolumn{3}{|c|}{ FE } & \multicolumn{3}{|c|}{ RE } \\
\hline & Coeff & t-stat & Prob & Coeff & t-stat & Prob & Coeff & t-stat & \\
\hline \multicolumn{10}{|l|}{$\mathrm{C}$} \\
\hline INTERNET & -0.002 & -0.106 & 0.916 & 0.001 & 0.050 & 0.960 & -0.003 & -0.234 & 0.815 \\
\hline BOARD & 0.103 & 1.528 & 0.128 & 0.112 & 1.287 & 0.199 & 0.101 & 1.691 & 0.092 \\
\hline OUTBOAR & 0.069 & 1.283 & 0.201 & 0.043 & 2.865 & $0.004^{* *}$ & 0.090 & 1.812 & 0.071 \\
\hline CONST & 0.052 & 1.878 & 0.062 & 0.401 & 6.818 & $0^{*}$ & 0.070 & 2.760 & 0.006 \\
\hline INST & 0.012 & 0.405 & 0.686 & 0.286 & 0.851 & 0.396 & 0.016 & 0.598 & 0.550 \\
\hline SIZE & -0.015 & -0.912 & 0.363 & -0.031 & -1.222 & 0.223 & -0.013 & -0.898 & 0.370 \\
\hline NPL & -0.016 & -5.884 & $0.0000^{*}$ & -0.010 & -3.278 & $0.0012^{*}$ & -0.016 & -6.630 & $0 *$ \\
\hline R-Square & 0.185 & & & 0.497 & & & 0.185 & & \\
\hline Adjusted R & 0.161 & & & 0.418 & & & 0.161 & & \\
\hline \multicolumn{4}{|c|}{ Hausman Test } & & 0 & & & & \\
\hline \multicolumn{4}{|l|}{ Chow Test } & & & & 0 & & \\
\hline
\end{tabular}

Sumber : diolah

*significant at the $1 \%, * *$ significant at the $5 \%$

Board size tidak berpengaruh terhadap kinerja perbankan, hal tersebut menunjukkan bahwa perusahaan sebaiknya lebih mempertimbangkan kualitas board of director-nya dibandingkan dengan kuantitas atau jumlah direktur (Lestari, 2018), yang diharapkan dapat memberikan lebih banyak insight untuk dapat meningkatkan kinerja perusahaan. Kepemilikan institusional tidak berpengaruh terhadap kinerja perbankan, hal tersebut mengindikasikan bahwa besarnya proporsi kepemilikan institusional masih dipandang menjadi hal negatif dan positif, perusahaan sebaiknya mempertimbangkan kepemilikan manajerial untuk menyeimbangkan dalam pengambilan keputusan (AL-Najjar, 2015).

Penelitian ini menunjukkan bahwa keberadaan dewan komisioner independen berpengaruh positif terhadap kinerja perbankan, yang mengindikasikan bahwa adanya komisioner independen dapat menciptakan transparansi yang lebih baik untuk meningkatkan kinerja. Berdasarkan pada kode tata kelola dan rekomendasi dari regulator, sebaiknya ada proporsi yang seimbang antara direktur, direktur independen, dan termasuk di dalam komisioner dan komisioner independen (Fuzi, Halim, \& Julizaerma, 2016). Selain itu, kepemilikan terkonsentrasi yang berpengaruh terhadap kinerja perusahaan mengindikasikan bahwa dengan adanya proporsi pengendalian yang sesuai maka akan mempermudah pengambilan keputusan sehingga berdampak terhadap kinerja yang lebih baik. 


\section{KESIMPULAN}

Kesimpulan dan Implikasi

Penelitian ini bertujuan untuk menganalisa pengaruh e-banking dan praktek penerapan good corporate governance terhadap kinerja perusahaan. Penelitian ini menunjukkan bahwa e-banking, board size, dan kepemilikan institusional tidak berpengaruh terhadap kinerja perbankan. Sedangkan komisioner independen dan kepemilikan terkonsentrasi berpengaruh terhadap kinerja perusahaan.

Perusahaan, sebaiknya melakukan evaluasi mengenai isu-isu maupun keputusan strategik, khususnya isu-isu yang terkait dengan tujuan efisiensi, seperti penggunaan teknologi, komposisi manajemen, dan proporsi kepemilikan. Perusahaan, khususnya perusahaan perbankan sebaiknya melakukan evaluasi terkait dengan adopsi e-banking. Edukasi mengenai penggunaan layanan tersebut dapat terus dilakukan dan tetap terus berinovasi, karena layanan keuangan berbasis digital yang diberikan oleh perusahaan perbankan hampir sama, sehingga proporsi pengaruhnya untuk meningkatkan kinerja sangatlah kecil.

\section{Keterbasan dan Saran}

Dalam penelitian ini, fokus dalam penggunaan e-banking dan praktek good corporate governance pada perusahaan perbankan yang terdaftar di Bursa Efek Indonesia dari tahun 2008 sampai dengan 2016. Dalam mengkaji mengenai adopsi teknologi, penelitian ini hanya menganalisa dari variabel ebanking. Untuk penelitian di masa yang akan datang, dapat ditambahkan variabel inovasi untuk menggali lebih jauh mengenai tingkat kreativitas dan inovasi perusahaan perbankan dalam menghadapi persaiangan pada era digital.

\section{REFERENSI}

AL-Najjar, D. (2015). The Effect of Institutional Ownership on Firm Performance: Evidence from Jordanian Listed Firms. International Journal of Economics and Finance; Vol. 7, No. 12, 97-105.

American Bankers Association. (2014). The Business of Banking: What Every Policy Maker Needs to Know. American Bankers Association .

Arora, A., \& Sharma, C. (2016). Corporate Governance and Firm Performance in Developing Countries: Evidence from India. Corporate Governance, Vol. 16 Issue 2, 420-436.

Brigham, E. \& Houston, J. F. (2006). Fundamental of Financial Management, Tenth Edition, USA: Thomson South Western College Publishing.

Clarkson, M., \& Deck, M. (1997). Effective Governance of Micro Finance Industry: Estimating a Micro Finance Industry. Establishing a Microfinance Industry.

DBS Group Research. (2018). Indonesian Banks . DBS Group Research.

Deloitte. (2016). Good Governance Driving Corporate Performance?: A meta-analysis of Academic Research \& Invitation to Engage in the Dialogue. Deloitte.

EY. (2017). The Indonesian Banking Industry: Unfolding the Opportunity. EY.

Fanta, A. B., Kemal, K. S., \& Waka, Y. K. (2013). Corporate Governance and Impact on Bank Performance. Journal of Finance and Accounting, Vol. 1, No.1, 19-26.

Furst, K., Lang, W. W., \& Nolle, D. E. (2000). Internet Banking: Developments and Prospects. Economic and Policy Analysis, Working Paper No. 2000-9.

Fuzi, S. F., Halim, A., \& Julizaerma. (2016). Board Independence and Firm Performance. Procedia Economics and Finance 37, 460-465.

Kombe, S. K., \& Wafula, M. K. (2015). Performance of Commercial Banks in Kenya a Case of Kenya Commercial Bank. International Journal of Scientific and Research Publications, Vol. 5, Issue 5, $1-10$. 
AKURASI, 1(1), 21-30

Wisnu Hardoyo Murti. Pengaruh E-Banking dan Good Corporate ...

Lestari, D. (2018). Corporate Governance, Capital Reserve, Non-Performing Loan,and Bank Risk Taking. International Journal of Economics and Financial, Vol 8, No. 2, 25-32.

Malholtra, P., \& Singh, B. (2009). The Impact of Internet Banking on Bank Performance and Risk: The Indian Experience. Eurasian Journal of Business and Economics, Vol. 2, No. 4, 43-62.

Okiro, K., \& Ndungu, J. (2013). The Impact of Mobile and Internet Banking on Performance of Financial Institutions in Kenya. European Scientific Journal, Vol.9, No.13.

Onakoya, A. B., Ofoegbu, D. I., \& Fasanya, I. O. (2012). Corporate Governance and Bank Performance: a Pooled Study of Selected Banks in Nigeria. European Scientific Journal December, Vol.8, No.28, 155-164.

Oxfordbusinessgroup.com. (2018, September 25). Technology Set to Transform Indonesian Banking. Diambil kembali dari https:// oxfordbusinessgroup.com/ analysis/ wireless-worldtechnology-changing-structure-sector-expanding-financial-inclusion-and-available.

PWC. (2018). Indonesia Banking Survey: Technology Shift in Indonesia is Underway. PWC.

Tunay, K., Tunay, N., \& Akhisar, I. (2015). Interaction Between Internet Banking and Bank Performance: The Case of Europe. Procedia - Social and Behavioral Sciences , vol. 195, 363368.

\section{PROFIL PENULIS}

Wisnu Handoyo Murti adalah dosen Prodi Akuntansi, Sekolah Tinggi Ilmu Ekonomi Indonesia Jakarta dengan pengalaman mengajar di bidang akuntansi seperti prinsip akuntansi, akuntansi manajemen, akuntansi biaya, dan sistem informasi akuntansi di tingkat sarjana. Penulis memiliki ketertarikan pada penelitian akuntansi, khususnya akuntansi manajemen. Wisnu Handoyo Murto adalah penulis koresponden dapat dihubungi di: wisnuhanmurti@gmail.com 
AKURASI: Jurnal Riset Akuntansi dan Keuangan

Published by LPMP Imperium 